\title{
Judicialization of Economic and Monetary Union: between a rock and a soft place? ${ }^{1}$
}

\author{
Judicialización de la Unión Económica y Monetaria: \\ ¿Entre la espada y la pared?
}

Nuno Albuquerque Matos

$\mathrm{PhD}$ Candidate at Catolica Global School of Law, Lisbon

nunoalbuquerquematos@gmail.com

Contents: 1. Introduction.-2. European Central Bank unconventional policies. - 3. Judicial review of ECB's action.-4. Bundesverfassungsgericht decision pursuant to Weiss. -5 . Institutional consequences. -6 . Back to basics: a look to the past to envision the future. -7 . Conclusion

\begin{abstract}
The European Central Bank has been active since the sovereign debt crisis that struck European Union Member States by putting in place several asset-purchasing programmes such as Outright Monetary Transactions and Public Sector Purchase Programme. As much as these decisions have proven the pivotal importance of this institution within the monetary union, they have also spurred controversy on potentially having exceeded the competences attributed to the Union. The german federal constitutional court heard challenges to both and requested the Court of Justice to decide on their validity within the framework of a preliminary ruling. The decision of the former court to declare the Public Sector Purchase Programme ultra vires - in this way countering the preliminary ruling decision - as well as its argumentation could produce many institutional consequences to both the European Central Bank and Court of Justice of the European Union. Finally, it has shown the limits of European Union integration and will inevitably propel discussions on which way to go in the future: it is time for this discussion to come out from courtrooms into the public sphere.

Keywords: Economic and Monetary Union; Monetary policy; Ultra vires; Gauweiller; Weiss.

Resumen: El Banco Central Europeo ha participado activamente desde la crisis de la deuda soberana que afectó a los Estados miembros de la Unión Europea, al poner en marcha varios programas de compra de activos, como el

1 The present article was generously funded by FCT - Fundação para a Ciência e Tecnologia, under PhD scholarship PD/BD/150292/2019.
\end{abstract}


Programa de Transacciones Monetarias Directas y el Programa de Compra del Sector Público. Si bien estas decisiones han demostrado la importancia fundamental de esta institución dentro de la unión monetaria, también han causado polémica por haber superado potencialmente las competencias atribuidas a la Unión. El tribunal constitucional federal alemán escuchó las impugnaciones de ambos y solicitó al Tribunal de Justicia que se pronunciara sobre su validez en el marco de una decisión prejudicial. La decisión de áquel de declarar ultra vires el Programa de Compras del Sector Público - de esta forma contrarrestando la decisión prejudicial-así como su argumentación, podrían producir muchas consecuencias institucionales, tanto para el Banco Central Europeo, como para el Tribunal de Justicia de la Unión Europea. Finalmente, ha mostrado los límites de la integración de la Unión Europea e inevitablemente impulsará las discusiones sobre qué camino tomar en el futuro: es hora de que esta discusión salga de los tribunales a la esfera pública.

Palabras clave: Unión Económica y Monetaria; Política Monetaria; Ultra vires; Gauweiller; Weiss.

\section{Introduction}

Central bankers have become widely known figures during the last decade. The 2007 crisis brought about the fragility of the world's financial system and central banks needed to step up and take center stage in stabilizing the world's economy by proving massive amounts of support.

While these rather uncommon monetary policies were not very contentious in many countries, this was not the case in the EU, as the active role taken by the ECB in stabilizing and preserving the integrity of the Eurozone's economy spurred a judicial debate over whether this increased intervention should be considered to be within the boundaries of the Treaties. The judicial challenge of two ECB decisions before the german federal constitutional court, and its subsequent engagement with the Court of Justice, are the epilogue of longstanding case law of the former regarding the assessment of the legality of acts of EU institutions, given the limits of EU integration and the way it views the relationship between EU and national legal systems.

As such, the present article will be divided in four parts. In part 2 we will provide a layout of the unconventional policies undertaken by the ECB that were judicially challenged. Setting the features of the two contentious ECB decisions - Outright Monetary Transactions and Public Sector Purchase Programme - will be important to understand the challenge brought before the german federal constitutional court, the questions it 
referred for preliminary ruling and how the Court of Justice tackled them, which we will address in part 3. Such paramount judicial decisions may bring about consequences in the way the ECB and the Court of Justice operate, which will be explored in part 4. Lastly, in part 5 we will endeavor to envision what the future might hold by looking at the past and reasoning around the way the EU integration has evolved.

\section{European Central Bank unconventional policies}

The ECB has adopted a discrete way of performing its mandate for the first years of existence, namely by resorting to the interest rate setting mechanism, during a period of relatively stable market. However, stability was severely affected in 2007 with the eruption of the worst financial crisis since the Great Depression. ${ }^{2}$ Unlike other central banks, this shift has not prompted the ECB to immediately change course ${ }^{3,4}$ and to adapt to extraordinary circumstances until a few years later.

This relatively slower pace of adaption has much to do with institutional, contextual and historical constraints. Indeed, it is recognized that the setting up of the ECB was conditioned to its resemblance of the Bundesbank, which was seen as the compromise for Germany to lose monetary policy control and render it to an independent institution inspired on its core values of price stability and conservatism. ${ }^{5}$ On the other hand, as Weiler portrays, the EU is a continuously evolving constitutional space, where institutional transformations take place, sometimes by way of

2 See, for instance, P. Krugman, "The Lesser Depression”, The New York Times, 21 July 2011, https://www.nytimes.com/2011/07/22/opinion/22krugman.html, accessed 20 June 2020; J. Bivens, "Worst economic crisis since the Great Depression? By a long shot", Economic Policy Institute, 27 January 2010, https://www.epi.org/publication/snapshot_20100127/, accessed 20 June 2020.

3 After Lehman Brothers filed for bankruptcy in September 2008, the US Federal Reserve System quickly decreased it for $1.50 \%$ (on October 8 th), $1 \%$ (on October 29th) and $0-0.25 \%$ (on December 16th). In contrast, the ECB had rates set at $4.75 \%$ (on October 8th), $4.25 \%$ (on October 9th and 15th) and ended 2008 at 3\%. On this, see https://www.federalreserve.gov/monetarypolicy/openmarket.htm and https://www.ecb.europa.eu/stats/policy_ and_exchange_rates/key_ecb_interest_rates/html/index.en.html, both accessed 20 June 2020 .

${ }^{4}$ For a thorough analysis of the institutional evolution spurred by the financial crisis, see J. C. Silva, Agências Europeias de Regulação (Gestlegal 2019), p. 384 and seq; T. Beukers, "The new ECB and its relationship with the eurozone Member States: between central bank independence and central bank intervention", 50 Common Market Law Review (2013), p. 1580.

${ }^{5}$ K. Tuori, The European Financial Crisis-Constitutional Aspects and Implications, (EUI Working Paper, Law 28/2012), https://cadmus.eui.eu/handle/1814/24301, accessed 15 May 2020; C. Kombos, "Constitutional Review and the Economic Crisis: In the Courts We Trust?”, 25 European Public Law (2019), p. 114. 
mutation, thus extending competences not foreseen when the Treaty of Rome and subsequent were agreed upon. ${ }^{6}$

The transformation of the ECB has taken place gradually, ${ }^{7}$ by adopting non-conventional measures during the Eurozone crisis. For the purposes of this paper, we will focus on the Securities Market Programme, Outright Monetary Transactions and the Public Sector Purchase Programme.

In 2010, the ECB announced the adoption of the Securities Market Programme, ${ }^{8}$ by implementing measures to address the "severe tensions in certain market segments which are hampering the monetary policy transmission mechanism and thereby the effective conduct of monetary policy oriented towards price stability in the medium term". ${ }^{9}$ The objective of the programme was "to address the malfunctioning of securities markets and restore an appropriate monetary policy transmission mechanism"10 and the scope of the interventions would be determined by the Governing Council. In an important remark, the ECB stated that this adoption was taken on condition of fiscal frugality. ${ }^{11}$ This programme was active essentially in the first half of 2010 and second half of 2011, however it did not prove effective in the long-term despite positive short-term effects, possibly due to its limited scope at the outset. ${ }^{12}$

As such, in 2012 it was replaced by Outright Monetary Transactions, whose objective was two-fold: (i) to restore an appropriate monetary policy transmission and (ii) to safeguard the singleness of monetary policy by lowering bond yields, thus reducing borrowing costs for Member States by providing confidence to investors in the sovereign-bond markets. The ECB framed the programme within its mandate of "define and implement the

6 J. Weiler, "The Transformation of Europe", 100 Yale Law Journal (1991), p. 2403. On EU constitutional changes see also K. Tuori and K. Tuori, The Eurozone Crisis: A Constitutional Analysis (Cambridge University Press 2014); B. De Witte, "Euro Crisis Responses and the EU Legal Order: Increased Institutional Variation or Constitutional Mutation?", 11 European Constitutional Law Review (2015), p. 434; M. Ioannidis, “Europe's new transformations: How the EU economic constitution changed during the Eurozone crisis", 53 Common Market Law Review (2016), p. 1237.

${ }^{7}$ For an overview of ECB intervention see T. Beukers, 50 Common Market Law Review (2013).

${ }^{8}$ See Decision of the European Central Bank of 14 May 2010 establishing a securities market programme (ECB/2010/5) (2010/281/EU), OJEU, L 124/8, 2010.

${ }^{9}$ Idem, recital 2.

10 Idem, recital 3.

11 Idem, recital 4.

12 M. Ioannidis, 53 Common Market Law Review (2016), p. 1255. See also M. Falagiarda and S. Reitz, "Announcements of ECB unconventional programs: Implications for the sovereign spreads of stressed euro area countries", 53 Journal of International Money and Finance (2015), p. 280. 
monetary policy of the Union", in accordance with article 127 (2) TFEU and article 3 of ECB Statute.

There are several features that characterize this programme. First, the ECB can purchase government-issued bonds maturing in one to three years on request of a government asking for financial assistance under the European Financial Stability Fund and European Stability Mechanism ${ }^{13}$ the conditionality principle. Most importantly, conditions must not only be agreed but also effectively implemented to enable eligibility. Second, in stark contrast with the previous programme, there are no ex ante quantitative limits on the size of transactions. Third, the ECB accepts the same (pari passu) treatment as private or other creditors with respect to bonds issued by euro area countries and purchased by the Eurosystem - no preferential treatment principle. Fourth, in order to prevent potential inflationary pressures, the liquidity created would be sterilized by conducting liquidity-absorbing operations of the corresponding amount to counter any effects on money supply. Finally, transparency, which implies that aggregate outright monetary transaction holdings and their market values to be published on a weekly basis. ${ }^{14}$

The Public Sector Purchase Programme was adopted by the ECB in 2015 , involving large-scale purchase of bonds issued by public entities in the Eurozone, mostly central governments, by the Eurosystem with the aim of increasing inflation. Indeed, the ECB frames the Decision within the purview of its mandate, affirming that "This decision was taken as part of the single monetary policy in view of a number of factors that have materially increased the downside risk to the medium-term outlook on price developments, thus jeopardising the achievement of the ECB's primary objective of maintaining price stability" ${ }^{15}$

On the proportionality of the Decisions, regarding Outright Monetary Transactions, there was a clear intention to frame the programme within the ECB's mandate of "define and implement the monetary policy of the Union", in accordance with article 127 (2) TFEU and article 3 ECB Statute. Although no bonds have actually been purchased under this program, this reasoning was conducted not only to address shortcomings in the EMU's

${ }^{13}$ For an overview, see M. Megliani, "From the European Stability Mechanism to the European Monetary Fund: There and Back Again”, 21 German Law Journal (2020), p. 674.

${ }_{14}$ ECB Press Release of 6 September 2012 at https://www.ecb.europa.eu/press/pr/ date/2012/html/pr120906_1.en.html, accessed 18 May 2020. In the doctrine, Falagiarda and Reitz, 53 Journal of International Money and Finance (2015), p. 280; D. Adamski, "Economic Constitution of the Euro Area After the Gauweiller Preliminary Ruling", 52 Common Market Law Review (2015), p. 1453.

15 Decision (EU) 2015/774 of the European Central Bank of 4 March 2015 on a secondary markets public sector asset purchase programme, OJEU L 121/20, recital 3. 
structure, namely the mismatch with decentralized fiscal policy, ${ }^{16}$ but also to address criticism, mainly from the german federal constitutional court. Outright Monetary Transactions was largely seen as a tipping point in the management of the EU sovereign debt crisis, particularly because of the way Mario Draghi (ECB's president at the time) managed market expectations with the whatever it takes statement. In a way, in that moment it was clear that flexibility was cornerstone, in opposition to an a priori defined and rigid system.

On Public Sector Purchase Programme, in order to justify its necessity, the ECB is also careful to provide context and describe the increasing steps it had taken until deciding for its adoption.

In an environment where key ECB interest rates are at their lower bound, and purchase programmes focusing on private sector assets are judged to have provided measurable, but insufficient, scope to address the prevailing downside risks to price stability, it is necessary to add to the Eurosystem's monetary policy measures the PSPP as an instrument that features a high transmission potential to the real economy. ${ }^{17}$

The ECB also deems the measure adequate, given that its portfolio rebalancing effect and the sizable purchase volume of the Public Sector Purchase Programme.

will further ease monetary and financial conditions, including those relevant to the borrowing conditions of euro area non-financial corporations and households, thereby supporting aggregate consumption and investment spending in the euro area and ultimately contributing to a return of inflation rates to levels below but close to $2 \%$ over the medium term $^{18}$.

This programme is therefore an extension of Outright Monetary Transactions in terms of conception and underlying idea. The substantive difference between the two programmes is of course the magnitude of intervention the former has entailed ${ }^{19}$.

16 See Adamski, 52 Common Market Law Review (2015), p. 1455.

17 Decision (EU) 2015/774, recital 4.

18 Idem.

19 At the end of May 2020, the PSPP holdings account for over 2 trillion euros, representing around 16\% of Eurozone's GDP in 2019 according to Eurostat, available at https:// ec.europa.eu/eurostat/tgm/refreshTableAction.. $\mathrm{do}$ ?tab=table \&plugin=1\&pcode=tec $00001 \&$ lan guage $=$ en, accessed 5 June 2020 . 


\section{Judicial review of ECB's action}

Judicial review of Outright Monetary Transactions and the Public Sector Purchase Programme was performed by the Court of Justice in Gauweiller $^{20}$ and Weiss ${ }^{21}$ respectively. In the present section we will analyze them separately.

\subsection{The Gauweiller case}

The Gauweiller case ${ }^{22}$ is to be considered a landmark case from the outset, not only because it was originated by the first ever preliminary ruling reference performed by the german federal constitutional court to the Court of Justice, but also (and most importantly) because it formally triggered a substantive constitutional interaction between these two High Courts on a set of issues related to EU integration and distribution of competences with Member States in a concrete, factual setting: the interpretation and implementation of EU Treaties by an EU institution. ${ }^{23}$

In essence, in the national proceedings before the german federal constitutional court, the applicants submitted (i) that Outright Monetary Transactions' decisions form an ultra vires act inasmuch as they are not covered by the mandate of the ECB and infringe Article 123 TFEU and (ii) that those decisions breach the principle of democracy entrenched in the german Constitution and thereby impair german constitutional identity. ${ }^{24} 25$

${ }^{20}$ Case C-62/14, Peter Gauweiler and Others v Deutscher Bundestag, EU:C:2015:400.

21 Case C-493/17, Heinrich Weiss and Others, EU:C:2018:1000.

22 On this case, in the doctrine, F. Fabbrini, "After the OMT Case: The Supremacy of EU Law as the Guarantee of the Equality of the Member States", 16 German Law Journal (2015), p. 1003; Adamski, 52 Common Market Law Review (2015); M. Kumm, "Rebel Without a Good Cause: Karlsruhe's Misguided Attempt to Draw the CJEU into a Game of 'Chicken' and What the CJEU Might to About It", 15 German Law Journal (2014), p. 203; V. Borger, "Outright Monetary Transactions and the stability mandate of the ECB: Gauweiler", 53 Common Market Law Review (2016), p. 139; M. Goldmann, "Adjudicating Economics? Central Bank Independence and the Appropriate Standard of Judicial Review", 15 German Law Journal (2014), p. 265.

${ }^{23}$ While the Court of Justice had already delivered an important ruling in Pringle, where the issue at hand there was substantively different, since it was related to whether the European Stability Mechanism - a treaty established under international law_ was to be considered compatible with EU law. See Case C-370/12, Thomas Pringle v Government of Ireland and Others, EU:C:2012:756.

${ }^{24}$ Case C-62/14, Peter Gauweiler and Others v Deutscher Bundestag, para. 6.

25 See F. Fabbrini and A. Sajó, "The dangers of constitutional identity", 25 European Law Journal (2019), p. 457, for other national and supranational courts using the same argument. See also W. Sadurski, “'Solange, chapter 3': Constitutional Courts in Central 
As such, the national court decided to stay the proceedings and refer essentially two question to the Court of Justice. First, whether Outright Monetary Transactions exceed the powers conferred to the ECB on monetary policy, as defined in the Treaties and, second, whether this Decision violates the primary law principle of monetary financing prohibition. While doing so, it also tried to pressure the Court into taking a certain course of review, stating at the outset that the ECB's mandate must be interpreted strictly in order to meet democratic requirements and that compliance with its limits must be subject to comprehensive - thus substantive - judicial review. ${ }^{26}$

\subsubsection{Acting ultra vires?}

The Court of Justice started by recalling that the Union has exclusive competence on monetary policy for Member States whose currency is the euro [article 3 (1) (c) TFEU], being the ECB and national central banks tasked to conduct that policy with independence (article $282 \mathrm{TFEU}$ ). Although the Treaties did not settle for a definition of monetary policy, they define the objectives it ought to pursue. Thus, the primary objective is to maintain price stability (interpreted by the ECB as meaning close but below $2 \%$ inflation). Without prejudice to that objective, monetary policy should also support the general economic policies in the Union, with a view to contribute to the achievement of its objectives, as laid down in Article 3 TEU. ${ }^{27}$

Given the clear mandate, the issue of whether the programme in question fits the mandate or, on the contrary, exceeds the powers Member States have conferred to the Union, was addressed. Building upon Pringle, the Court established a delimitation between monetary and economic policy, stating that in order to determine whether a measure falls within the area of monetary policy it is necessary to take into account the objectives of that measure as well as the instruments used to implement it. ${ }^{28}$

In order to frame Outright Monetary Transactions as monetary in nature, the Court stated a number of reasons. First, since monetary policy must be single, the objective of safeguarding its singleness does not exceed the mandate. Second, the objective of safeguarding an appropriate transmission of monetary policy is likely to attain the referred singleness

Europe - Democracy - European Union”, 14 European Law Journal (2008), p. 1; M. Claes, "The protection of national constitutional identity and the limits of european integration at the occasion of the Gauweiler case", 16 German Law Journal (2015), p. 917.

26 Case C-62/14, Peter Gauweiler and Others v Deutscher Bundestag, para. 8-10.

27 Idem, para. 34-45.

28 Idem, para. 46. 
but also to maintain price stability. The reason for this is that the mechanisms used to transmit the ECB's monetary policy effectively are essential in impacting price developments. Therefore, disrupting these mechanisms necessarily affect the ability to guarantee price stability. And while monetary policy decisions might also spill over to economic policy matters (such as to contribute to the stability of the Euro area) that circumstance does not change its inherent nature. ${ }^{29}$

In what concerns the means of implementation by resorting to outright monetary transactions on the secondary sovereign debt markets, the ECB Statute grants the possibility of buying and selling outright marketable instruments. The fact that the transactions would not entail a general approach and, on the contrary, would embody a selective nature was not seen as problematic either, as the fragmentation of monetary policy transmission was not homogeneous. As such, a targeted bond buying programme would be adequate to address the identified shortcomings. ${ }^{30}$

The Court also rejected the claim that the economic policy nature of the decision derives from the conditionality principle. While it is true that compliance with an European Financial Stability Fund or European Stability Mechanism macroeconomic adjustment programme might produce economic policy effects, those effects should be considered as indirect and should not be treated as equivalent. In a forceful argument, it stressed that the conditionality principle is also essential to respect the subsidiarity principle on economic policy decisions, in that a monetary policy intervention might relax economic conditions and indicators which could have justified adjustment efforts had that involvement not taken place. We would also add that the breaking of monetary policy transmission was much due to heterogeneous economic and fiscal conditions which made Member States creditworthiness and risk perception to vary widely. As such, the better the economic circumstance, the least monetary policy would have to undertake in unconventional measures to ensure its effective implementation. ${ }^{31}$

Finally, the Court assessed the programme as complying with the proportionality test, setting the framework early on by stating that the ECB is to be granted a broad discretion given the "choices of a technical nature and to undertake forecasts and complex assessments", which it must conduct with all care and accuracy. Nevertheless, that does not mean that the institution is exempt from judicial review. In fact, the more discretion enjoyed the more fundamental it is to comply with procedural guarantees

\footnotetext{
29 Idem, para. 48-52.

${ }^{30}$ Idem, para. 53-56.

31 Idem, para. 57-65
} 
and to conduct compliance review, which includes at least a two-fold obligation: (i) carefully and impartially examine all relevant elements of the situation and (ii) provide an adequate statement of reasons. On appropriateness, the Court extensively relied on economic assessments made by the ECB, according to which several Member States were experiencing severe volatility on their risk premia, which consequently fragmented monetary policy transmission, namely bank refinancing and credit costs. As such, the measure was deemed adequate as no manifest error of assessment was identified..$^{32}$

The programme was also deemed necessary as the ECB affirmed in the proceedings that the mere announcement was sufficient to restore monetary policy transmission and, perhaps consequently, was never actually implemented. Moreover, a series of safeguards were implemented, such as the conditionality principle and the limitations in scope to bonds maturing up to three years. All this allowed the Court to conclude that Outright Monetary Transactions had not gone beyond what was necessary to achieve its objectives. ${ }^{33}$

\subsubsection{In breach of the principle of prohibition of monetary financing?}

Article 123 (1) TFEU states that

Overdraft facilities or any other type of credit facility with the European Central Bank or with the central banks of the Member States (hereinafter referred to as 'national central banks') in favour of Union institutions, bodies, offices or agencies, central governments, regional, local or other public authorities, other bodies governed by public law, or public undertakings of Member States shall be prohibited, as shall the purchase directly from them by the European Central Bank or national central banks of debt instruments

From the above stated provision derives the prohibition from purchasing bonds on the primary market which does not preclude acquisitions on the secondary market (from Member States creditors). Naturaliter, such possibility is not without limitations, as the Court stated that such action should not have an equivalent effect to direct purchases, meaning that the acquisitions must not discourage countries from pursuing sound budgetary policies by way of artificially lowering market pressure. This would take place in practice, according to the Court, if potential

32 Idem, para. 66-74.

33 Idem, para. 75-92. 
purchasers on the primary market were certain that the ECB would subsequently take their securities in its portfolio within a certain period of time. In this respect, it is noted that the Outright Monetary Transactions' operation (scope, start, continuation and suspension) was neither predetermined nor was there any prior announcement on its beginning. A series of safeguards were also considered relevant to significantly mitigate the risk of reducing impetus of sound budgetary policy: bond maturity limitation; possibility of selling bonds at any time; Member States need to resume access to the market and compliance with structural adjustment programmes.$^{34}$ All in all, the residual effect was considered reasonable and within the consequences that any potential monetary policy decision can entail.

\subsection{The Weiss case}

Is this EMU constitutional saga, the Weiss case ${ }^{35}$ is also to be considered to be a pivotal one, albeit for different reasons, namely the german federal constitutional court's subsequent decision for the ultra vires nature of the Public Sector Purchase Programme, ${ }^{36}$ in divergence with what the Court of Justice had determined in the preliminary ruling response.

The questions referred by the national court in its preliminary ruling were similar to those in Gauweiller. Thus, the Court ruled on several questions, such as monetary policy nature; proportionality review; prohibition of monetary financing. Once again, the Court of Justice upheld the measures adopted by the ECB, very much relying on the Gauweiller case law. However, similarities between both decisions on monetary policy are only apparent, as already laid out supra.

\subsubsection{Public Sector Purchase Programme as monetary policy}

On whether the programme rests within the remit of monetary policy, following Gauweiller the Court of Justice started discussing its objectives.

34 Idem, para. 93-127.

35 On this case, A. Lang, “Ultra vires review of the ECB's policy of quantitative easing: An analysis of the German Constitutional Court's preliminary reference order in the PSPP case", 55 Common Market Law Review (2018), p. 923; Marijn Van Der Sluis, "Similar, Therefore Different: Judicial Review of Another Unconventional Monetary Policy in Weiss (C-493/17)", 46 Legal Issues of Economic Integration (2019); M. Dawson and A. Bobic, "Quantitative Easing at the Court of Justice - Doing whatever it takes to save the euro: Weiss and others", 56 Common Market Law Review (2019), p. 1005.

36 BVerfG, Judgment of the Second Senate of 05 May 2020 - 2 BvR 859/15. 
In this regard, the Court found that the objective is to return inflation rates below, but close to, $2 \%$ over the medium term, which is in line with the primary objective with EU's monetary policy. This conclusion was not hindered by the fact that the programme brought about considerable effects on economic policy measures. Because that is precisely a secondary monetary policy objective - to support general economic policies of the Union - the Treaties did not intend to draw an absolute line between economic and monetary policies. As noted in Gauweiller, the Court emphasized that indirect economic effects produced by an ECB Decision cannot prompt one to consider a monetary policy measure as equivalent. The Court of Justice also rejected the german federal constitutional court's assertion that knowingly accepted and foreseeable effects of a measure should be considered as indirect effects and, as such, precluded from adoption, by adding that if that were to be the case the European System of Central Banks (ESCB) would be prevented from using the means available in the Treaties to pursue its primary objective which might represent an "insurmountable obstacle". As the instruments are foreseen in the ECB Statute, the Court declared that both the objectives and the means are covered under Treaty provisions. ${ }^{37}$

\subsubsection{Proportionality of the Public Sector Purchase Programme}

After noting the Gauweiller case-law on the broad discretion enjoyed by the ECB, the Court justified the necessity of this programme with reference to countering a decrease in prices over the medium term. To this end, it resorted to documentation produced by the ECB arguing for a high level of risk of deflation in December 2014 (with the rate of inflation at $-0.2 \%$ ) despite the monetary policies adopted, with grim economic forecasts (up to November 2016 - the inflation rate was at $0.6 \%$ ). Against this backdrop and with reference to other central banks' practice and various studies on the efficacy of large-scale purchases of government bonds to meet the inflation target, the Court found no manifest error of assessment. $^{38}$

The Court of Justice then assessed whether it meets the adequacy test. In this regard, the Court affirms the measure was taken in the context of the risk of triggering a deflationary cycle and that it was not foreseeable that different, less intensive, programmes could have achieved the primary objective of monetary policy. Other features were also considered, such as

37 Idem, para. 53-70.

38 Idem, para. 71-78. 
the non-selective nature, stringent eligibility criteria, temporary nature, purchase limits per issue and per issuer. The successive extensions of the programme and the substantial size of its purchases were seen as adequate in light of insufficient changes in inflation rates. Finally, the loss-sharing framework was considered to be adequate. Indeed, in order to prevent spillovers from potential economic deterioration from other Member States, not only were national central banks instructed to purchase assets primarily from their own States but also the securities eligible are those of international organizations (which represent $10 \%$ of the total value of the programme).${ }^{39}$

\subsubsection{Prohibition of monetary financing}

The two-step test developed in Gauweiller was applied in order to determine the compatibility of the the Public Sector Purchase Programme with article 123 (1) TFEU.

First, the Court assessed whether purchases on the secondary market do not have an equivalent effect to purchases on the primary market, as the german federal constitutional court claimed that it creates a de facto certainty that private acquisitions will be subsequently purchased by the ECB. While acknowledging that a certain degree of certainty is deliberately provided, the Court underlined that the amount and type of safeguards that characterized the programme are sufficient enough to counter that effect (particularly the blackout periods, the discretion of the Governing Council in the execution, the acquisition of different types of bonds, the limitations per issue and issuer)..$^{40}$

Second, it leaned over the question of Member States' reduced impetus to conduct sound budgetary policy. In assessing this criterion, the Court adopted a similar approach in listing those restrictions as sufficient safeguards to prevent the lack of incentives to pursue sound economic policies. ${ }^{41}$

The national court also stated that holding bonds until maturity and purchasing bonds at a negative yield to maturity could breach the prohibition of monetary financing. The Court did not agree, arguing that not only is there nothing in the ECB Statute to preclude it, but also because it remains for the ECB to assess whether and when it is appropriate to sell securities. In addition, it is not implied that payment is not demanded if those assets were to be held until payment is due. Of course, holding until

\footnotetext{
39 Idem, para. 79-100.

40 Idem, para. 109-128.

${ }^{41}$ Idem, para. 129-144.
} 
maturity takes pressure off countries in that it does not increase the offer of securities in the market. However, as the Court acknowledged, these economic effects should be considered as indirect and, therefore, under the scope of the Treaties. ${ }^{42}$

Acquisitions of bonds at negative yields to maturity were also considered in line with the Treaties as they are acquired in secondary markets, do not hinder sound budgetary policies (since emissions at negative rates imply a good fiscal position) and will actually make it more difficult for private operators to identify which Member States' bonds will be purchased in the future. ${ }^{43}$

\section{Bundesverfassungsgericht decision pursuant to Weiss}

As already mentioned above, the german federal constitutional court did not follow what the Court of Justice of the EU had determined in the response to the preliminary ruling request, as it disagreed on a number of issues. ${ }^{44}$

On the standard of review, the german court manifested that it was not satisfied that the Court of Justice of the EU had granted the ECB an ample margin of appreciation. In fact, it stated that when fundamental interests of the Member States are affected, judicial review must go further than accepting ECB's positions at face value. Crucially, in the absence of closer scrutiny and broad discretion, the integrity of Member States' competences may be at risk, with the tantamount consequences to the principle of conferral - one of the cornerstone principles of EU integration - and, consequently, to the principle of democracy. ${ }^{45}$

The application of the principle of proportionality might hinder the principle of conferral, according the Bundesverfassungsgericht. On this matter, proportionality of the monetary policy measure - namely suitability and necessity - had to be assessed in connection with the economic effects it creates. The german constitutional court is, in effect, calling for a balancing test to be conducted, one where the programme's monetary policy objectives and the economic policy effects are identified, weighed and balanced against one another. Conversely, where monetary policy objectives are pursued unconditionally - and its economic policy effects are ignored - it disregards the principle of proportionality. ${ }^{46}$

\footnotetext{
42 Idem, para. 145-152.

43 Idem, para. 153-157.

${ }_{44}$ BVerfG, Judgment of the Second Senate of 05 May 2020.

45 Idem, para. 142.

46 Idem, para. 138-145.
} 
Regarding the prohibition of monetary financing, the german constitutional court affirms that the assessment of the compatibility of a programme with such principle should be conducted by resorting to an overall assessment of the circumstances. In particular, the purchase limit of $33 \%$ and the distribution of purchases according to the European Central Bank's capital key prevent selective measures being taken under the Public Sector Purchase Programme for the benefit of individual Member States and the Eurosystem becoming the majority creditor of one Member State. ${ }^{47}$

However, in case the risk-sharing regime were subject to changes, this would affect the limits set by the overall budgetary responsibility of the german Bundestag and amount to an assumption of liability for decisions taken by third parties with potentially unforeseeable consequences, which is not admissible under the Constitution. ${ }^{48}$

Based on the foregoing, the Federal Constitutional Court declared the ECB decision to be ultra vires and required the Federal Government and the Bundestag to take steps seeking to ensure that the ECB conducts a proper proportionality assessment. ${ }^{49}$

\section{Institutional consequences}

This tension between national constitutional courts - with the german federal constitutional court being the most prominent example ${ }^{50}-$ and the Court of Justice over ultra vires acts sparked a number of consequences that could significantly change the way EU institutions function going forward, namely the ECB (and national central banks) as well as the Court of Justice.

\footnotetext{
47 Idem, para. 197-212.

48 Idem, para. 222-228.

49 Idem, para. 229-232.
}

${ }^{50}$ On cases regarding the relationship between Member States and the Union, see D. Thym, "In the name of sovereign statehood: A critical introduction to the Lisbon judgment of the german constitutional court", 46 Common Market Law Review (2009), p. 1785; J. Ziller, "The German Constitutional Court's Friendliness towards European Law: On the Judgment of Bundesverfassungsgericht over the Ratification of the Treaty of Lisbon", 16 European Public Law (2010), p. 53; A. Von Bogdandy and S. Schill, "Overcoming absolute primacy: respect for national identity under the Lisbon Treaty", 48 Common Market Law Review (2011), p. 1417; M. Payandeh, "Constitutional review of EU law after Honeywell: Contextualizing the relationship between the german constitutional court and the EU Court of Justice”, 48 Common Market Law Review (2011), p. 9. 


\subsection{Independence of the ECB. Where does accountability lie?}

The principle of independence of the ECB is enshrined in article 130 and 282 (3) TFUE and Article 7 of the ECB Statute. The ECB is obliged not to seek or receive instructions from other Union institutions, bodies, offices or agencies or from any Member State. These, in turn, are under a duty to abstain from interfering and influencing decision-making bodies of the ECB. In this vein, this principle has been interpreted as independence from political rather from legal interference, ${ }^{51}$ which is to say that the ECB and national central banks are meant to be shielded from political pressures for short-term interests and, rather, pursue their objectives and act in accordance with their competences in order to develop medium to long-term policies in a credible way. This is not to say that political accountability should not take place, quite the opposite. Political accountability is an essential part of the democratic legitimacy of the ECB but should be understood as a periodic assessment of performance and accountability structures. ${ }^{52}$

Despite stemming directly from EU primary law, this (operational) independence does not hinder legal accountability. As stated in article 263 TFEU "The Court of Justice of the European Union shall review the legality of legislative acts, of acts of the Council, of the Commission and of the European Central Bank [...]".

Consequently, the problem does not lie on whether the ECB is independent from political pressure or from judicial review. On the contrary, it is a matter of degree and interpretation of its role, given that the degree of accountability is indirectly proportional to the latitude provided: the greater flexibility to define and implement its mandate, the lesser judicial control and vice versa. This is indeed a crucial point to be noted since it explains that the disagreements between both courts derive from some misconceptions.

On the one hand, the german federal constitutional court considers that ECB's independence should be interpreted narrowly since it conflicts with the principle of democracy and the right of the german people to selfdetermination ${ }^{53}$ but also because, historically, it was seen as a pre-condition

51 See G. Majone, "Two logics of delegation: Agency and fiduciary relations in EU governance", 2 European Union Politics (2001), p. 103; M. Dawson and A. Bobic, 56 Common Market Law Review (2019), p. 1028.

${ }^{52}$ For instance by the European Parliament. See also H. Lelieveldt and S. Princen, The Politics of the European Union (Cambridge University Press 2015). See also T. Beukers, 50 Common Market Law Review (2013), p. 1618.

${ }^{53}$ BVerfG, Order of the Second Senate of 18 July 2017 - 2 BvR 859/15, para. 102-103. René Smits also argues that ECB independence is only acceptable if it is accompanied by a clear mandate. See R. Smits, The European Central Bank. Institutional Aspects (Kluwer 
for Germany's accession to the EMU ${ }^{54}$ that the ECB's features mirror those of the german Bundesbank.

However, the national court may possibly be failing to fully absorb historical limitations and contextual peculiarities. ${ }^{55}$ First, it is conceivable that the framers of Treaties did not foresee a crisis of the scale and magnitude of the sovereign debt crisis. In addition, EU institutions have always paved the way of integration when Member States would not (or could not) do it by themselves. To this end, the Court's early case-law was - and still is - critical to set up what is known for European economic constitution. Secondly, the Treaties have embraced a dynamic role for the $\mathrm{ECB}$, not only because of the drafting of a generic mandate within a prescriptive Treaty, but also of the evolving nature of EU integration, its challenges, the transformation of EU institutions and their relationship with Member States. As such, too strict a reading of the Treaties might entail the risk of not fully capturing the spirit of the legal provisions.

Thirdly, the ECB might be propelled to act more boldly also because of the known EMU incompletion on the fiscal side ${ }^{56}$ and the pressure it entails on the uniform transmission of monetary policy.

On the other hand, the Court of Justice of the EU reasoning is the opposite: precisely because the ECB emerged as an EU institution with a special nature and status, having merited numerous independence-related provisions in primary law, the Court considers this a justification for a milder standard of review.

However, in performing this interpretation, the Court of Justice of the EU is perhaps awarding excessive freedom for the ECB in defining its role as an independent central bank, with limited accountability from other institutions.$^{57}$ Also, it is possibly holding different EU institutions to a different standard of review. In Gauweiller and Weiss, it has argued in favor of judicial deference because of the broad discretion and economic

Law International 1997), p. 178. See also M. Dawson and A. Bobic, 56 Common Market Law Review (2019), p. 1029.

${ }^{54}$ See C. Gerner-Beuerle et al., "Law meets economics in the german Federal Constitutional Court: Outright Monetary Transactions on Trial", 15 German Law Journal (2014), p. 295.

55 See A. Lang, 55 Common Market Law Review (2018), p. 938.

56 See W. Oates, "Fiscal federalism in theory and practice: applications to the European community", Commission of the European Communities 1977; L. Pacheco, "Fiscal federalism, EMU and shock absortion mechanisms: A guide to the literature", 4 European Integration Online Papers (2000), http://eiop.or.at/eiop/pdf/2000-004.pdf, accessed 10 June 2020; M. Evers, "Federal fiscal transfer rules in monetary unions", 56 European Economic Review (2012), p. 507; W. Oates, "Toward a second-generation theory of fiscal federalism", 12 International Tax and Public Finance (2005), p. 349.

57 See M. Dawson and A. Bobic, 56 Common Market Law Review (2019), p. 1030. 
expertise enjoyed by the ECB. However, over the years it has been very stringent with the European Commission, namely regarding competition policy, frequently challenging its reasoning, asking for additional supporting information and, not infrequently, annulling decisions.

It seems that both Courts place themselves at different ends of the spectrum, which of course leads to very different reasonings and conclusions. Although the standard of review of ECB's actions will be more developed infra, it suffices to say here that the Court of Justice of the EU should not dismiss itself from a substantive standard of review of an EU institution because of its high degree of independence. Quite the opposite should take place. In addition, the german constitutional court should adopt a holistic approach to the Treaties and recognize that the ECB was given a broad mandate that should not be strictly confined to pursuing price stability by way of the adoption of a conventional monetary policy.

\subsection{Monetary policy and economic policy. Is there a Chinese wall in between?}

A different issue is related to whether monetary policy and economic policy should be understood as being separate species or intrinsically intertwined.

Article 3 TFEU is clear in entrusting exclusive competence on monetary policy to the Union, whereas the enactment and implementation of economic policy is left to each Member State, in coordination with the others (article 5, 120 and seq. TFEU).

The question is not straightforward and has been extensively discussed.$^{58}$ While there is broad agreement on the connections between monetary policy and other policies, namely financial stability and fiscal policies, there are mainly two schools of thought on the normative consequences.

The separation theory school favors a monetary policy that largely disregards other policies, guided by strict rules in order to sustain a steady development of money supply and prevent political pressure. This school of thought rejects programmes of quantitative easing such as applied by the FED or by the ECB.

On the other hand, the interdependence theory school considers that there are a number of reasons why central banks should consider economic policy when taking their decisions, for instance to monitor the developments of private and public credit. If before the 2008 financial

58 See, for all, M. Goldmann, 15 German Law Journal (2014), p. 269. 
crisis, credit bubbles were seen as an issue pertaining to financial sector supervision, since then it is acknowledged that there is an intrinsic relation between monetary policy and the volume of credit in an economy. Consequently, if loose monetary policy may fuel a credit bubble, a very tight one - one that aims to restrict amounts of money supply below the necessary for economic growth - may risk deflation. Additionally, if a central bank exhausts the effectiveness of its conventional tool, i.e. if setting interest rates at $0 \%$ or below does not suffice to pick up inflation, then other - unconventional - measures would need to be taken. This is what we have been observing in central bank activity around the world in the years subsequent to the crisis and is what the ECB started with Outright Monetary Transactions and later with the Public Sector Purchase Programme.

The Court of Justice had this contextual factor in mind when it mentioned that Treaty founders did not intend to draw an absolute separation between monetary and economic policies, so much so that the ECB is required to pursue the economic interests of the Union as long as it is compatible with maintaining price stability. Thus, monetary policy has always been regarded as potentially being able to affect the economy and rightly so.

When setting up the EMU, Member States drew a line between monetary and economic policy not for technical but for political reasons. The currency is a symbol to which citizens relate with and, consequently, an important feature to the development of social bondage and to the creation of a common identity. Therefore, Member States thought that the agreement on the existence of a common European currency - the eurowas a necessary leap for the transformation of EU integration. In fact, the bedrock of integration up until the Maastricht Treaty had been the furtherance of the single market. While it is true that this objective was very much a product of EU institutions' effort - particularly the European Commission and the Court of Justice of the EU - it is also true that the underlying reason is economic in nature: Member States decided to progressively reduce or eliminate restrictions to the Treaties' four freedoms in order to create a bigger market where everyone would be better off in economic terms (from reducing the costs and increasing the volume of trade; providing a vast array of new products to consumers and fostering competition). Crucially, at its very core, the single market is a product of cooperation between countries where all of them have overwhelmingly much more to gain than to lose, rather than a pooling of sovereignty. By creating the EMU, Member States intrinsically changed the nature of integration into a process where - to a certain degree - there is a blurring of sovereignty. From that moment on, Member States interests and - to a certain degree - fates became increasingly intertwined and interdependent. 
From the foregoing derives that economic and fiscal policy - the ability to allocate and redistribute resources obtained by setting up of different kinds of taxes - is one of the few policies very much linked to national sovereignty left within the exclusive competence of Member States. As such, the only Chinese wall in place was introduced by political reasons. However, that does not change the nature of things, which is that monetary policy influences economic policy just as much as the latter can have a toll on the former.

But what happens when monetary policy is stretched almost to the point of exhaustion, to the point where it needs the fiscal side to work on its behalf and to create relevant spillover effects towards monetary policy? We consider this to be the ECB's mindset since the Outright Monetary Transactions decision.

Lastly, the german federal constitutional court took the potential (negative) indirect fiscal effects of Outright Monetary Transactions and the large (negative fiscal) risks in the ECB's portfolio within the Public Sector Purchase Programme as the defining feature when assessing the nature of the measures. It did not endeavor to assess the proportionality of either measure, for instance by taking those effects into account among other considerations. By not doing so, one may question where is the line to be drawn? In other words, at what point does a measure stop being monetary and start being economic in nature? How much economic effects would be necessary to overcome the monetary objective in defining the nature of the measure? ${ }^{59}$ These questions remain unanswered.

\subsection{Procedural or substantive review of ECB action?}

Procedural review has its merits. As explained by Lenaerts, "Structuralism is a theory of US constitutional adjudication according to which courts should seek to improve the decision-making process of the political branches of government so as to render it more democratic" ${ }^{6} 0$

While not making the case for structuralism to be adopted by the Court as the leading theory of judicial review, the author outlines several case-law from the Court of Justice in order to argue that review of process is a way to make sure that, where an EU Institution (e.g. EU legislator) enjoys broad discretion, abuses are prevented. From this perspective, procedural review

59 Van Der Sluis, 46 Legal Issues of Economic Integration (2019), p. 271.

${ }^{60}$ K. Lenaerts, "The European Court of Justice and Process-Oriented Review", 31 Yearbook of European Law (2012), p. 3. See also D. Harvey, "Towards process-oriented proportionality review in the European Union”, 23 European Public Law (2017), p. 93. 
has a two-fold advantage: it increases judicial scrutiny over the decisionmaking process of EU institutions while preventing the Court from diving into political realm. ${ }^{61}$ In his words, "the ECJ is more respectful of the prerogatives of the political institutions of the EU if it rules that, when adopting the contested act, those institutions failed to take into consideration all the relevant interests at stake, than if it questions their policy choices by reference to its own view of the issues involved" ${ }^{62}$

Lenaerts further teaches that "Courts lack the power of the purse and that of the sword. It is only thanks to their independence and impartiality as well as the quality of their reasoning - that their rulings enjoy authority and legitimacy". ${ }^{63}$ Despite referring to Member State courts, these features are horizontal, applicable to all judicial instances and, naturaliter, to the Court of Justice as well. As such, a proper procedural review embodies important values, such as promotion of transparency, justification, pluralism and institutional respect and balance. This brief excerpt emboldens those that conclude that substantive judicial review of monetary/ economic matters to be an extremely difficult task - given its specificity and lack of scientific preparation by judges - one that should be carefully conducted, if at all, and mindful of pitfalls, calling for neither a full-judicial review nor a mere procedural review but for a "rationality check": to assess whether a certain decision is rationally justifiable. ${ }^{64}$

Although Gauweiller and Weiss are not to be interpreted as blank checks, given the amount of conditionality the Court places on the ECB, there is a sense of "institutional empowerment", as stated by Tridimas and Xanthoulis. ${ }^{65}$ For some, this is a disappointing part of the decisions because the Court did not engage in a thorough, substantive, proportionality review $^{66}$ such as called for by the german federal constitutional court. By

${ }^{61}$ K. Lenaerts, 31 Yearbook of European Law (2012), p. 15.

62 Idem. For instance, the Vodafone case shows how prior legislative assessment and subsequent judicial review contributes to a better legislative process. See Case C-58/08, Vodafone and Others, EU:C:2010:321.

${ }^{63}$ K. Lenaerts, "New Horizons for the Rule of Law Within the EU", 21 German Law Journal (2020), p. 31.

${ }^{64}$ M. Goldmann, 15 German Law Journal (2014), p. 271; D. Dyzenhaus, "Process and substance as aspects of the public law form", 74 Cambridge Law Journal (2015), p. 284; See also J. Ely, Democracy and Distrust - A Theory of Judicial Review (Harvard University Press 1980).

65 T. Tridimas and N. Xanthoulis, "A legal analysis of the Gauweiller case: between monetary policy and constitutional conflict", 23 Maastricht Journal of European and Comparative Law (2016), p. 31.

66 M. Dawson and A. Bobic, 56 Common Market Law Review (2019), p. 1023; M. Dawson, et al., "Reconciling independence and accountability at the European Central Bank: The false promise of Proceduralism", 25 European Law Journal (2019), p. 75. 
doing so, the later is assessing if law in books resembles law in action. In other words, are the objectives of the Public Sector Purchase Programme commensurate to the practical effects in European economy? The procedural review conducted in these cases could also be on edge since the Court did not seem to assess the adequacy of procedures themselves, which would call for more information gathering from independent sources, not almost exclusively from the ECB. ${ }^{67}$

It is clear that each court demands a certain standard of review depending on the adopted perspective on the role the ECB should undertake. In practice, again with Tridimas and Xanthoulis and as seen supra, it seems that the ECB is an institution whose political accountability is very mild. As such, judicial deference would make it immune to virtually any type of scrutiny, at odds with the principles of rule of law and democracy. However, judicial deference is precisely fitting with the special nature of the ECB as an institution whose independence is directly enshrined in various provisions of primary law..$^{68}$

While in Gauweiller, judicial deference seemed reasonable given that the programme had not yet been applied at the time of the decision (and was not applied at all, as referred supra), the same exercise is not as clearcut in Weiss, since the Public Sector Purchase Programme entails extensive purchases. As correctly observed by Harvey, it is a question of threshold, of

what will it take to convince the CJEU that all relevant facts and considerations have been taken into account? What precisely is required of the law-maker when demonstrating that it based its measures on 'objective criteria'? In light of the wide discretion afforded to the lawmaker, is the Court willing to engage in the substantive contents of such justificatory evidence? ${ }^{69}$

In the case-law of the Court where it grants broad discretion, e.g. for EU legislature, it seems evidence is accepted at face value, thus lacking a proper judgment on the merits of its content, e.g. impact assessment reports. ${ }^{70}$ The same issue arises in Gauweiller and Weiss. Indeed, by resorting almost entirely to evidence submitted by the ECB and accepting it at face value without an adequate degree of scrutiny, namely the choices of

67 M. Dawson and A. Bobic, 56 Common Market Law Review (2019), p. 1033.

${ }_{68}$ Tridimas and Xanthoulis, 23 Maastricht Journal of European and Comparative Law (2016), p. 32.

69 D. Harvey, 23 European Public Law (2017), p. 117.

70 For instance see Case C-310/04 Spain v Council, EU:C:2006:521; Case C-58/08, Vodafone and Others; Case C-176/09, Luxembourg v Parliament and Council, EU:C:2011:290. 
a technical nature and forecasts and complex assessments, not only applicants may be precluded from challenging their methodology or findings but also, and most importantly, it could be anticipated that the ECB will continue to resort to such procedural strategy. ${ }^{71}$

It is up to the Court of Justice to decide if and how it will start to dive into the merits of such contextual or preparatory documentation, or whether it will continue to almost blindly accept ECB decisions that (formally) state the pursuance of monetary policy goals and that complex assessments have been undertaken. After Gauweiller, the window was still open. After Weiss, that may no longer be the case.

\subsection{Prohibition of monetary financing}

The raison d'être of article 123 (1) TFEU is that the impetus provided by private bond markets for Member States to pursue sound fiscal policies is not lessened by the easing of monetary conditions by public authorities, i.e. the ECB and national central banks. Consequently, purchases in Member States bond auctions (primary market) are prohibited. Both unconventional ECB programmes aim at making asset purchases in the secondary markets (where private operators trade bonds between themselves), consequence of which is that it makes such market more liquid by increasing demand for bonds. The high(er) demand signals the perception of low(er) risk and, consequently, the premia tend to reduce.

It is against this background that the german federal constitutional court questions whether these operations produced an effect equivalent as primary purchases, in that a de facto certainty of ECB bond-buying could be created on the market, thus artificially lowering pressure. From this court's perspective, the public information concerning ECB's activity and the possibility of holding bonds until maturity provided a degree of certainty in the market that could be incompatible with the principle of prohibition of monetary financing. Blackout periods without prior announcement, despite effective in not influencing prices, would however hinder effective judicial review.

There is once more a clear dichotomy of approaches. As referred supra, in Gauweiller the Court of Justice set a number of safeguards that would prevent violation of article 123 (1) TFEU, such as the lack of certainty on whether, when, which and for how long the purchases would take place; the incentive for conducting sound fiscal policies by Member States;

71 D. Harvey, 23 European Public Law (2017), p. 120. 
limitations for holding assets until maturity; conditionality principle. With conscience that it could have created a stringent set of criteria for the future, the Court added a more flexible tone while assessing the Public Sector Purchase Programme, stating that the characteristics of each programme and the economic context need to be taken into consideration as well.

\subsection{Transparency and effectiveness}

Transparency is another mechanism to ensure institutions are held accountable. A fortiori, this is more relevant to institutions that have (a high degree of) independency, such as the ECB. Thus, independence, accountability and transparency are values that run in tandem or are sides of the same coin. ${ }^{72}$

As Benoît Coeuré puts it "Independence ensures that the ECB can act in line with its mandate. Accountability, on the other hand, ensures that the ECB does act in line with its mandate [...]" (our bold). ${ }^{73}$

In addition, "Transparency is crucial to the ECB's work and it attaches great importance to communicating effectively with the public. Transparency helps people understand the ECB's monetary policy, and better public understanding, in turn, makes the ECB's monetary policy more credible and effective". ${ }^{74}$ Therefore, an independent, accountable and transparent ESCB can better convey confidence in its action, by allowing it to more effectively distance itself from political interference be it ex-ante (at the decision-making level) be it ex-post (decision review or political accountability process).

However, from the Weiss case it is legitimate to question whether the effectiveness of ECB's action would not be hindered if we were to fully embrace transparency. Or, admitting that a non-transparent ECB would not be acceptable by democratic standards, what would the sufficient degree of transparency underlying ECB's action be? It seems that the german federal constitutional court places the ECB between a rock and a hard place: on the one hand, transparency is considered essential in order to fully enable courts to conduct substantive judicial review; on the other hand, it seems that both the national court and the Court of Justice admit that if the ECB were fully transparent, then it would be in violation of the principle of

72 M. Dawson and A. Bobic, 56 Common Market Law Review (2019), p. 1034; M. Dawson et al., 25 European Law Journal (2019), p. 81.

73 B. Coeuré, "Independence and accountability in a changing world", 28 March 2017, https://www.ecb.europa.eu/press/key/date/2017/html/sp170328_1.en.html, accessed 16 June 2020.

74 Idem. 
prohibition of monetary financing, because it would allow a sufficient level of public information allowing markets to anticipate next steps and, as such, produce an effect equivalent to acquiring Member States bonds on the primary market. The Court tackled the matter by arguing that the duty to state reasons is complied with if the lack of transparency is necessary to ensure uncertainty in the markets as long as the underlying reasons to justify it are set out and are compelling.

Even as that may be, while the german court's approach seems contradictory, it also has the utility to place at breathtaking plane sight some of the paradoxes of EU integration, in particular those of the EMU.

\section{Back to basics: a look to the past to envision the future}

Albert Einstein had a remarkably famous statement whereby "If you want to know the future, look at the past". As such, in times of (constitutional) crisis it is wise to have a look back to the foundations built over time and reason around them to envision what the future might hold. The pillars of EU integration have been set for a long-time, not only in the case-law but also by Member States: principles such as direct effect and primacy of EU Law; sincere cooperation between EU and national judiciary; equality between Member States; national political and constitutional identity ${ }^{75}$ are cornerstones of the EU.

All these principles run in tandem with each other. It is worth noting that they were created in the context, and because of, the Second World War. In order to secure lasting peace, countries knew that economic, cultural and social cooperation and interconnection was of paramount importance, but there was also a fundamental need to create a normative framework whereby they could voluntarily enter into and according to which they should abide for on an equal basis. The referred principles are, therefore, as different as they are complementary of each other. Direct effect and primacy of EU Law as an autonomous legal order, but in

75 See M. Kumm, "Who is the final arbiter of constitutionality in Europe?: Three conceptions of the relationship between the german Federal Constitutional Court and the European Court of Justice", 36 Common Market Law Review (1999), p. 351; F. Fabbrini, 16 German Law Journal (2015); F. Fabbrini and A. Sajó, 25 European Law Journal (2019); J. C. Vilaça, "O acórdão do tribunal constitucional alemão e o tribunal de justiça - cooperação judicial ou diálogo de surdos?”, 2 CERIDAP (2020), p. 38; N. ArribaSellier, "Between Karlsruhe and Luxembourg, lies Frankfurt? The Bundesbank and the Bundesverfassungsgericht's PSPP decision”, EU Law Live, May 2020, <https://eulawlive. com/op-ed-between-karlsruhe-and-luxembourg-lies-frankfurt-the-bundesbank-and-thebundesverfassungsgerichts-pspp-decision-by-nathan-de-arriba-sellier/>, accessed 5 June 2020. 
dialogue between judicial institutional structures. Direct effect and primacy of EU Law, insofar as Member States are equal before it and with respect of national diversity.

At its core, the EU is a manifestation of multilateralism, which means that each State is willing and knowingly adhering to a structure that has some kind of supranational set of bodies in order to ensure the existence of proper mechanisms that channel national sensitivities into a decisionmaking process that may ultimately not produce an outcome which totally resembles the views of any of them, but which is respected and abided for insofar as it is perceived as having been conducted with equity, fair treatment and in respect for the rule of law.

Consequently, it is essential that such normative framework enjoys primacy (not supremacy) ${ }^{76}$ over national frameworks and to have an impartial, independent and equidistant judicial body to enforce it. Only these features may deliver equality of Member States. On the one hand, it is in our opinion a misread to state that EU and national frameworks run in tandem. They do not and they cannot. If that were to be the case, there would be no legal certainty and a very difficult equilibrium to reach consensus. Take the Weiss case as an example: while it is true that the german federal constitutional court has called the Public Sector Purchase Programme ultra vires, is this reading shared among the other 26 constitutional courts? ${ }^{77}$ Even in the unlikely event of a positive answer, would this methodology be appropriate as a rule, given the different cultural features, legal inspirations and sociological preferences across the EU? ${ }^{78}$

${ }^{76} \mathrm{EU}$ law is not supreme in the sense that it completely ignores national legal frameworks, cultural and social differences among Member-States. On the contrary, article 4 (2) TEU enshrines in primary law the principles of national identity, sincere cooperation and equality before the Treaties. Article 5 embodies, among others, the principle of subsidiarity, which is aimed to respect national idiosyncrasies. As such, all these principles are necessarily taken into account by EU institutions when taking decisions. In this sense, see F. Fabbrini, 16 German Law Journal (2015), p. 1012, and J. C. Vilaça, 2 CERIDAP (2020), p. 42. With a different view, see A. Bobic and M. Dawson, "What did the German Constitutional Court get right in Weiss II?", EU Law Live, May 2020, https://eulawlive.com/op-ed-what-did-the-german-constitutional-court-get-right-in-weiss-iiby-ana-bobic-and-mark-dawson/, accessed 5 June 2020.

77 In this regard, the Portuguese Constitutional Court took a decision on July 15th 2020 that added a twist by concluding that the Constitutional Court can only refuse the application of a rule of EU law if it is incompatible with the fundamental principle of the democratic rule of law which, within EU law and Court of Justice jurisprudence, does not enjoy equivalent parametric material value recognized in the Constitution. If such equivalence is established and is functionally ensured by the Court of Justice, the Constitutional Court refrains from assessing compatibility with the Constitution. See https://www.tribunalconstitucional.pt/tc/ acordaos/20200422.html, accessed 20 July 2020.

${ }^{78}$ For criticism of the identity principle as vague and arbitrary, see F. Fabbrini and A. Sajó, 25 European Law Journal (2019). 
On the other hand, only supranational institutions can represent a range of diversity of 27 Member States with 450 million people and a different, albeit shared, history. As José da Cruz Vilaça wisely states

The principles of direct effect and primacy are the legal instruments that guarantee this result. It has been peaceful for 60 years [...], that these principles constitute the pillars of the Community legal order and a condition of its own existence. In a complex structure like that of the European Union - a sort of plural constitutionalism at various levels - the existence of competing "constitutional" courts in the same space cannot be accepted, in order to prevent the creation of a Union of variable geometry and, at the limit, generalized institutional chaos. Nor is it possible to select which "national identities to safeguard" or grant privileged status to any national constitutional court - or even assign to it the role of representative of everyone else. [... $]^{79}$ (our translation and bolds).

We would concur with Joseph Weiler and Daniel Sarmiento in affirming that the severe damage to the integrity of EU's legal order cannot be overlook or overstated ${ }^{80}$ Indeed

In the name of the rule of law, the rule of law was breached; in the name of proportionality, the German court trammeled all over the exigencies of proportionality in the delicate, dialogical, relationship between Member State courts and the Court of Justice; and complaining about the alleged 'incomprehensibility' of the Court of Justice's decision, the BVerfG issued a decision of which even Germany's most authoritative commenters regard the reasoning, though clear as a matter of language, incomprehensible in its legal logic. ${ }^{81}$

79 J. C. Vilaça, 2 CERIDAP (2020), p. 43.

${ }^{80}$ See J. Weiler and D. Sarmiento, "The EU judiciary after Weiss - Proposing a new mixed chamber of the Court of Justice", EU Law Live, June 2020, https://eulawlive.com/oped-the-eu-judiciary-after-weiss-proposing-a-new-mixed-chamber-of-the-court-of-justice-bydaniel-sarmiento-and-j-h-h-weiler/, accessed 12 July 2020.

${ }^{81}$ Idem. In the same vein see President of the Bundesgerichtshof (german Federal Court of Justice), P. Beck, "Ultra Vires?", D'Kart Antitrust Blog, May 2020, https://www.d-kart.de/en/ blog/2020/05/11/ultra-vires/, accessed 7 June 2020; T. Marzal, "Is the BVerfG PSPP decision "simply not comprehensible"?", Verfassungsblog, May 2020, https://verfassungsblog.de/is-thebverfg-pspp-decision-simply-not-comprehensible/, accessed 7 June 2020.

Regarding the german federal constitutional court's preliminary ruling request in Gauweiller, see Bundesverfassungsgericht, "Principal proceedings ESM/ECB - Pronouncement of the judgment and referral for a preliminary ruling to the Court of Justice of the European Union", Press Release No 9/2014, 7 February 2014, available at https://www.bundesverfassungsgericht. de/SharedDocs/Pressemitteilungen/EN/2014/bvg14-009.html, accessed 2 July 2020, two justices wrote dissenting opinions arguing that the Constitutional Court should not interfere with acts that are to be taken by the Bundestag and Federal Government. 
From a judicial framework perspective, these authors have proposed the creation of a new appeal jurisdiction within the Court of Justice, strictly confined to cases like Weiss, for two reasons: first, because there is no appeal from a decision pursuant to a preliminary ruling request; second, because the Court has been too lenient in safeguarding the limits of EU competences. ${ }^{82}$ José da Cruz Vilaça would prefer to create an alert system between the Court of Justice and national constitutional and supreme courts, in order to prevent to overburden an already heavy structure at the former. ${ }^{83}$ Anyway, we share the remarks of the latter author in that while this is a problem that has emerged in legal proceedings, it has a political nature, so there is only so much the judicial branch can do to address and resolve an issue that needs to be tackled politically. ${ }^{84}$

The german federal constitutional court and other national constitutional courts discussion over the limits of EU competences also resembles US constitutional history, ${ }^{85}$ where frequent and passionate criticism over the legitimacy of Supreme Court's authority occurred until the end of the Civil War in 1865 - 78 years after the enactment of the US Constitution in 1787 - only to start decreasing from there on.

Resembling the current situation in the EU, such challenge also occurred during the period of consolidation of US federal power, where a pronounced legal discussion was held over how far federal powers should reach. In Martin v Hunter Lessee case in 1816, the Supreme Court reversed a decision issued by the Virginia Court of Appeals, commanding it to obey. However, the later refused to abide, arguing the Supreme Court's decision to be ultra vires. Two main arguments were made in order to sustain that claim. First, because the US Constitution was silent on how to resolve disputes over federal and state boundaries. The reason for this silence, it was argued by the Virginia Court of Appeals, was the belief that by granting a permanent power on federal branches of government to control the states, it would be counter-productive and, consequently, the Supreme Court's intervention should be limited.

Secondly, the Virginia Court of Appeals stated that, pursuant to the principle of appellate review, a court would be superior in relation to the tribunal whose decisions it reviews, which meant that the Supreme Court would be superior only regarding lower federal courts. What is more, the State Court argued that an overriding of Supreme Courts' decisions would

82 J. Weiler and D. Sarmiento, EU Law Live, June 2020.

83 J. C. Vilaça, 2 CERIDAP (2020), p. 48.

${ }^{84}$ Idem, p. 49.

${ }^{85}$ See S. Boom, "The European Union after the Maastricht decision: Will Germany be the "Virginia of Europe"?", 43 The American Journal of Comparative Law (1995), p. 177. 
be equal to affirming its prevalence over foreign nations courts. In effect, what Virginia Court envisaged is not only a parallel system where both layers are disconnected from each other, but also a proclamation of US States' independence.

In the appeal from the referred refusal to abide for a previous Supreme Court's decision, this institution re-affirmed the supremacy of its decisions on legal and policy grounds. First, it stated that it held jurisdiction over all cases under the laws of the United States, independently of the appeal court. Second, that the Supremacy Clause would lose its effectiveness if the founders of the US Constitution meant that cases under the scope of the judicial power of the US could be decided by state courts. However, these were not the most significant arguments. Crucially, the Supreme Court developed the notion that uniformity of federal law was a fundamental policy goal, in the sense that if a single people created the Constitutions, then they should be subject to a single body of law. This would, however, not be possible if state courts' decisions were not reviewable. ${ }^{86}$

However, as the Steve Boom depicts, "the issue in the United States has been an interplay of law and politics. Legal foundation was fundamental but ultimately insufficient; political acceptance had to be won as well" ${ }^{87}$ In effect, an intense political debate and opposition occurred in tandem with the legal one. For the purposes of this article, suffice to say that States' opposition was not only conducted judicially, but also legislatively and by proposing constitutional amendments. The reasons for rejection of Supreme Court jurisdiction are varied. First, the Constitution had not been enacted by the people, rather by the acts of sovereign and independent states. Second, as an extension of the previous argument, concerns of lack of uniformity of application of federal law were to be dismissed given that such consequence should be considered as natural given the nature of the US as a group of independent governments. ${ }^{88}$

Again, the picture in the EU portrays some similarities. In fact, although there is a good deal of support for the primacy of EU law, there has been a number of challenges on the Court of Justice of the EU's jurisdiction by national constitutional courts, mostly on national identity grounds. At its core, these challenges resemble the independent nature of Member States on economic and fiscal policy issues and their weariness to politically accept the interdependence originated by EMU and its consequences.

\footnotetext{
86 Idem, p. 186-193.

${ }^{87}$ Idem, p. 202.

88 Idem, p. 194-201.
} 


\section{Conclusion}

The EMU was confronted with an unprecedented challenge that required tantamount action. In order to counter deflationary pressures, the ECB adopted expansionary policies for the first time in its history which triggered a lively debate on whether such actions were in accordance with EU Treaties and basic principles of the german constitution.

Gauweiller and Weiss place different approaches in contrast. The german federal constitutional court adopts a strict approach to the issue of EU Treaties interpretation and to the legal accountability due to be exercised by Courts. For the german Court, this review must take the form of appraisal of ECB decisions on its merits. On the contrary, the Court of Justice reads the Treaties in a flexible way and assesses such actions on the grounds of respect for due decision making process. In a way, it seems that the ECB is between a rock and a soft place.

Both approaches have pitfalls and entail serious issues going forward. The rock approach would have hindered action by the ECB in transmitting its monetary policy evenly, preserving the integrity of euro and, with it, possibly EU survival. The soft place approach empowers the ECB to a point where it risks making it an institution subject to mere formal checks and balances, with virtually no effective legal accountability. Perhaps the recent german judicial stance was a consequence of the lenient approach adopted by the Court of Justice or was just inevitable given its case law history. In any case, given the increasing institutional specialization within the EU, judicial deference on these grounds may put the Court within a complex place in the future.

These constitutional dialogues are neither recent nor is the german federal constitutional court by itself as other national courts also question the acts of EU institutions. It also resembles US constitutional history, marked by prolonged and vehement challenges to Supreme Court legitimacy by many State courts. However, this should not mean that the matter should be taken lightly. Ultra vires designation of an EU act by a national court, as in Weiss, would already be a serious issue of ultra vires judicial review. A fortiori, deciding over a preliminary ruling by the Court on the same proceedings affirming the legality of the measure, is legally not comprehensible.

The bigger picture though, is that this tension points to the heart of incomplete $E(M) U$ integration. Since monetary policy is an exclusive competence of the Union, unlike economic policy, it is doubtful that the judicial branch has the ability to settle this matter, given its simultaneous political nature. We came to a point where possibly the EU has stretched the current legal framework to its limits. It is time to take this discussion out of court rooms and bring it the public sphere, discussing where Europeans want to go from this point on. 


\section{Bibliography}

Ana Bobic and Mark Dawson, "What did the German Constitutional Court get right in Weiss II?", in EU Law Live, May 2020, available at https://eulawlive.com/ op-ed-what-did-the-german-constitutional-court-get-right-in-weiss-ii-by-anabobic-and-mark-dawson/

Andrej Lang, "Ultra vires review of the ECB's policy of quantitative easing: An analysis of the German Constitutional Court's preliminary reference order in the PSPP case", in Common Market Law Review, issue 55, 2018

Armin Von Bogdandy and Stephan Schill, "Overcoming absolute primacy: respect for national identity under the Lisbon Treaty", in Common Market Law Review, issue 48, 2011

Benoît Coeuré, "Independence and accountability in a changing world", Introductory Remarks, Brussels, 28 March 2017, available at https://www.ecb.europa. eu/press/key/date/2017/html/sp170328_1.en.html

Bruno de Witte, "Euro Crisis Responses and the EU Legal Order: Increased Institutional Variation or Constitutional Mutation?", in European Constitutional Law Review, issue 11, 2015

Bundesverfassungsgericht, "Principal proceedings ESM/ECB - Pronouncement of the judgment and referral for a preliminary ruling to the Court of Justice of the European Union”, Press Release No 9/2014, 7 February 2014, available at https://www.bundesverfassungsgericht.de/SharedDocs/Pressemitteilungen/ $\mathrm{EN} / 2014 /$ bvg14-009.html

Carsten Gerner-Beuerle, Esin Küçük and Edmund Schuster, "Law meets economics in the german Federal Constitutional Court: Outright Monetary Transactions on Trial", in German Law Journal, vol. 15, 2014

Constantinos Kombos, "Constitutional Review and the Economic Crisis: In the Courts We Trust?”, in European Public Law, issue 25, 2019

Daniel Thym, "In the name of sovereign statehood: A critical introduction to the Lisbon judgment of the german constitutional court", in Common Market Law Review, issue 46, 2009

Dariusz Adamski, "Economic Constitution of the Euro Area After the Gauweiller Preliminary Ruling", in Common Market Law Review, issue 52, 2015

David Dyzenhaus, "Process and substance as aspects of the public law form", in Cambridge Law Journal, Vol. 74, 2015

Darren Harvey, "Towards process-oriented proportionality review in the European Union", in European Public Law, issue 23, 2017

Decision of the European Central Bank of 14 May 2010 establishing a securities market programme (ECB/2010/5) (2010/281/EU), OJEU, L 124/8, 2010

Decision (EU) 2015/774 of the European Central Bank of 4 March 2015 on a secondary markets public sector asset purchase programme (ECB/2015/10), OJEU, L 121/20, 2015

ECB Press Release of 6 September 2012 at https://www.ecb.europa.eu/press/pr/ date/2012/html/pr120906_1.en.html

Federico Fabbrini, "After the OMT Case: The Supremacy of EU Law as the Guarantee of the Equality of the Member States", in German Law Journal, vol. 16, 2015 
Federico Fabbrini and András Sajó, “The dangers of constitutional identity”, in European Law Journal, issue 25, 2019

Giandomenico Majone, "Two logics of delegation: Agency and fiduciary relations in EU governance", in European Union Politics, vol. 2, 2001

Herman Lelieveldt and Sebastiaan Princen, The Politics of the European Union, Cambridge University Press, 2015

Jacques Ziller, “The German Constitutional Court's Friendliness towards European Law: On the Judgment of Bundesverfassungsgericht over the Ratification of the Treaty of Lisbon", in European Public Law, issue 16, 2010

João Nuno Calvão da Silva, Agências Europeias de Regulação, Gestlegal, 2019

John Bivens, "Worst economic crisis since the Great Depression? By a long shot", in Economic Policy Institute, January 27, 2010

John Ely, Democracy and Distrust - A Theory of Judicial Review, Harvard University Press, 1980

José Luís da Cruz Vilaça, “O acórdão do tribunal constitucional alemão e o tribunal de justiça - cooperação judicial ou diálogo de surdos?”, in CERIDAP, issue 2, 2020

Joseph Weiler, "The Transformation of Europe", in Yale Law Journal, volume 100, 1991

Joseph Weiler and Daniel Sarmiento, "The EU judiciary after Weiss - Proposing a new mixed chamber of the Court of Justice", in EU Law Live, June 2020, available at https://eulawlive.com/op-ed-the-eu-judiciary-after-weiss-proposing-a-newmixed-chamber-of-the-court-of-justice-by-daniel-sarmiento-and-j-h-h-weiler/

Kaarlo Tuori, The European Financial Crisis-Constitutional Aspects and Implications, EUI Working Paper, Law 28/2012

Kaarlo Tuori and Klaus Tuori, The Eurozone Crisis: A Constitutional Analysis, Cambridge University Press, 2014

Koen Lenaerts, "The European Court of Justice and Process-Oriented Review", in Yearbook of European Law, vol. 31, 2012

Koen Lenaerts, "New Horizons for the Rule of Law Within the EU", in German Law Journal, issue 21, 2020

Luís Pacheco, "Fiscal federalism, EMU and shock absortion mechanisms: A guide to the literature", European Integration Online Papers, issue 4, 2000

Marijn Van Der Sluis, "Similar, Therefore Different: Judicial Review of Another Unconventional Monetary Policy in Weiss (C-493/17)", in Legal Issues of Economic Integration, issue 46, 2019

Matteo Falagiarda and Stefan Reitz, "Announcements of ECB unconventional programs: Implications for the sovereign spreads of stressed euro area countries", in Journal of International Money and Finance, issue 53, 2015

Mark Dawson and Ana Bobic, "Quantitative Easing at the Court of Justice - Doing whatever it takes to save the euro: Weiss and others", in Common Market Law Review, issue 56, 2019

Mark Dawson, Adina Akbik and Ana Bobic, "Reconciling independence and accountability at the European Central Bank: The false promise of Proceduralism”, in European Law Journal, vol. 25, 2019

Matthias Goldmann, "Adjudicating Economics? Central Bank Independence and the Appropriate Standard of Judicial Review", in German Law Journal, vol. 15, 2014 
Mattias Kumm, "Who is the final arbiter of constitutionality in Europe?: Three conceptions of the relationship between the german Federal Constitutional Court and the European Court of Justice", in Common Market Law Review, issue 36, 1999

Mattias Kumm, "Rebel Without a Good Cause: Karlsruhe's Misguided Attempt to Draw the CJEU into a Game of 'Chicken' and What the CJEU Might to About It”, in German Law Journal, vol. 15, 2014

Mauro Megliani, "From the European Stability Mechanism to the European Monetary Fund: There and Back Again", in German Law Journal, issue 21, 2020

Mehrdad Payandeh, "Constitutional review of EU law after Honeywell: Contextualizing the relationship between the german constitutional court and the EU Court of Justice", in Common Market Law Review, issue 48, 2011

Michael Evers, "Federal fiscal transfer rules in monetary unions", European Economic Review, issue 56, 2012

Michael Ioannidis, "Europe's new transformations: How the EU economic constitution changed during the Eurozone crisis", in Common Market Law Review, issue 53,2016

Monica Claes, "The protection of national constitutional identity and the limits of european integration at the occasion of the Gauweiler case", in German Law Journal, vol. 16, 2015

Nathan Arriba-Sellier, "Between Karlsruhe and Luxembourg, lies Frankfurt? The Bundesbank and the Bundesverfassungsgericht's PSPP decision", in EU Law Live, May 2020, available at https://eulawlive.com/op-ed-between-karlsruheand-luxembourg-lies-frankfurt-the-bundesbank-and-the-bundesverfassungsgerichts-pspp-decision-by-nathan-de-arriba-sellier/

Paul Krugman, “The Lesser Depression”, in The New York Times, July 21, 2011

Peter Beck, "Ultra Vires?", in D'Kart Antitrust Blog, May 2020, available at https://www.d-kart.de/en/blog/2020/05/11/ultra-vires/

René Smits, The European Central Bank. Institutional Aspects, Kluwer Law International, 1997

Steve Boom, "The European Union after the Maastricht decision: Will Germany be the "Virginia of Europe"?", in The American Journal of Comparative Law, vol. 43,1995

Takis Tridimas and Napoleon Xanthoulis, "A legal analysis of the Gauweiller case: between monetary policy and constitutional conflict", in Maastricht Journal of European and Comparative Law, issue 23, 2016

Toni Marzal, "Is the BVerfG PSPP decision "simply not comprehensible"?", in Verfassungsblog, May 2020, available at https://verfassungsblog.de/is-thebverfg-pspp-decision-simply-not-comprehensible/

Thomas Beukers, "The new ECB and its relationship with the eurozone Member States: between central bank independence and central bank intervention", in Common Market Law Review, issue 50, 2013

Vestert Borger, "Outright Monetary Transactions and the stability mandate of the ECB: Gauweiler”, in Common Market Law Review, issue 53, 2016

Wallace Oates, "Fiscal federalism in theory and practice: applications to the European community", in Commission of the European Communities, 1977 
Wallace Oates, "Toward a second-generation theory of fiscal federalism", International Tax and Public Finance, issue 12, 2005

Wojciech Sadurski, “'Solange, chapter 3': Constitutional Courts in Central Europe -Democracy- European Union”, in European Law Journal, vol. 14, 2008

\section{Sobre el autor}

Nuno Albuquerque Matos es Licenciado y Máster en Derecho por la Universidad de Coimbra, donde también realizó estudios de posgrado en Derecho Bancario y de la Competencia de la UE. Doctorando en la Global School of Law de la Universidad Católica Portuguesa, en Lisboa. Asesor jurídico del Banco de Portugal y profesor invitado de la Universidad Católica Portuguesa. Autor de publicaciones (monografía, libros colectivos y artículos en revistas especializadas) en las areas del Derecho de Ayudas Estatales de la UE, Derecho de Competencia, Gobernanza y Finanzas Públicas de la UE.

\section{About the author}

Nuno Albuquerque Matos holds a Bachelor in Law and a Master degree in EU law from the University of Coimbra where he also undertook post-graduate studies in EU competition and banking law. $\mathrm{PhD}$ candidate at the Global School of Law of Portuguese Catholic University, in Lisbon. Legal adviser at the Bank of Portugal and guest lecturer at the Catholic University of Portugal. Author of publications (monograph, collective books and articles in specialized journals) in the fields of EU state aid law, competition law, EU governance and EU public finance. 


\section{Derechos de autor}

Los derechos de autor (para la distribución, comunicación pública, reproducción e inclusión en bases de datos de indexación y repositorios institucionales) de esta publicación (Cuadernos Europeos de Deusto, CED) pertenecen a la editorial Universidad de Deusto. El acceso al contenido digital de cualquier número de Cuadernos Europeos de Deusto es gratuito inmediatamente después de su publicación. Los trabajos podrán leerse, descargarse, copiar y difundir en cualquier medio sin fines comerciales y según lo previsto por la ley; sin la previa autorización de la Editorial (Universidad de Deusto) o el autor. Así mismo, los trabajos editados en CED pueden ser publicados con posterioridad en otros medios o revistas, siempre que el autor indique con claridad y en la primera nota a pie de página que el trabajo se publicó por primera vez en CED, con indicación del número, año, páginas y DOI (si procede). Cualquier otro uso de su contenido en cualquier medio o formato, ahora conocido o desarrollado en el futuro, requiere el permiso previo por escrito del titular de los derechos de autor.

\section{Copyright}

Copyright (for distribution, public communication, reproduction and inclusion in indexation databases and institutional repositories) of this publication (Cuadernos Europeos de Deusto, CED) belongs to the publisher University of Deusto. Access to the digital content of any Issue of Cuadernos Europeos de Deusto is free upon its publication. The content can be read, downloaded, copied, and distributed freely in any medium only for non-commercial purposes and in accordance with any applicable copyright legislation, without prior permission from the copyright holder (University of Deusto) or the author. Thus, the content of CED can be subsequently published in other media or journals, as long as the author clearly indicates in the first footnote that the work was published in CED for the first time, indicating the Issue number, year, pages, and DOI (if applicable). Any other use of its content in any medium or format, now known or developed in the future, requires prior written permission of the copyright holder. 